\title{
The Geography of Undocumented Mexican Migration
}

\author{
Douglas S. Massey \\ Jacob S. Rugh \\ Brigham Young University - Provo, jacob_rugh@byu.edu \\ Karen A. Pren \\ Princeton University
}

Follow this and additional works at: https://scholarsarchive.byu.edu/facpub

Part of the Race and Ethnicity Commons

\section{Original Publication Citation}

Massey, Douglas S., Jacob S. Rugh, and Karen A. Pren. 2010. "The Geography of Undocumented Mexican Migration," Mexican Studies/Estudios Mexicanos 26(1): 129-152.

\section{BYU ScholarsArchive Citation}

Massey, Douglas S.; Rugh, Jacob S.; and Pren, Karen A., "The Geography of Undocumented Mexican Migration" (2010). Faculty Publications. 3978.

https://scholarsarchive.byu.edu/facpub/3978

This Peer-Reviewed Article is brought to you for free and open access by BYU ScholarsArchive. It has been accepted for inclusion in Faculty Publications by an authorized administrator of BYU ScholarsArchive. For more information, please contact ellen_amatangelo@byu.edu. 


\title{
The Geography of Undocumented Mexican Migration
}

\author{
Douglas S. Massey \\ Jacob S. Rugh \\ Karen A. Pren \\ Princeton University
}

Using data from Mexico's Matrícula Consular program, we analyze the geographic organization of undocumented Mexican migration to the United States. We show that emigration has moved beyond its historical origins in west-central Mexico into the central region and, to a lesser extent, the southeast and border regions. In the United States, traditional gateways continue to dominate, but a variety of new destinations have emerged. California, in particular, has lost its overwhelming dominance. Although the geographic structure of Mexico-U.S. migration is relatively stable, it has nonetheless continued to evolve and change over time.

Este artículo analiza la geografía de los inmigrantes mexicanos indocumentados en los Estados Unidos utilizando datos del Programa de Matrícula Consular de México. Se muestra que la emigración se ha movido más allá de los orígenes históricos del occidente de México hacia la región central y, en un menor grado, al sureste y región fronteriza. En los Estados Unidos, las regiones tradicionales de destino continúan dominando, pero una nueva variedad de destinos han surgido. En particular, California ha perdido su dominio abrumador. Aunque la estructura geográfica de la migración México-Estados Unidos es relativamente estable, ésta ha continuado evolucionando y cambiando a través del tiempo.

Key Words: Mexico, Mexican Immigration, Geography, Undocumented Migration, Migrant Origins, Migrant Destinations, Migration Flows.

Palabras clave: México, inmigración mexicana, geografía, migración de indocumentados, orígenes migratorios, destinos de la migración, rutas migratorias.

Mexican Studies/Estudios Mexicanos Vol. 26, Issue 1, Winter 2010, pages 129-152. ISSN 0742-9797 electronic ISSN 1533-8320. (C2010 by The Regents of the University of California. All rights reserved. Please direct all requests for permission to photocopy or reproduce article content through the University of California Press's Rights and Permissions website, at http://www.ucpressjournals.com/reprint info.asp. DOI: 10.1525/msem.2010.26.1.129 
The geographic origins and destinations of Mexico-U.S. migrants have long been of interest to immigration researchers, going back to the seminal work of Gamio (1930) and Taylor (1934) and extending through to recent studies by Durand, Massey, and colleagues (Durand, Massey, and Charvet 2000; Durand, Massey, and Zenteno 2001; Durand and Massey 2003; Massey and Capoferro 2008). The data sources most commonly used to study the geography of Mexico-U.S. migration are censuses and surveys. In Mexico, the Census of Population and the Encuesta Nacional de la Dinámica Demográfica ask which household members have been to the United States over the preceding five years. Tabulating those who answer affirmatively by state and municipality yields a snapshot of the geographic origins of recent U.S. migrants, and cross-classifying them by individual, family, and household characteristics offers a socioeconomic profile (see Massey and Zenteno 2000; Durand, Massey, and Zenteno 2001). Likewise, the U.S. Census and Current Population Survey asks place of birth and year of entry for those born abroad, enabling demographers to examine the distribution of Mexican migrants by state, county, and metropolitan area and to measure trends in migrant characteristics by period of entry (see Massey and Capoferro 2008).

This reliance on census and survey data to study Mexican immigration has several drawbacks, however. First, these sources do not distinguish migrants by legal status, and the resulting distributions represent some unknown combination of documented and undocumented persons. Second, they do not connect places of origin with points of destination, making it impossible to study specific migratory flows. Although we can identify Mexican immigrants living at different locations in the United States, we do not know where in Mexico these people came from; and although we can tabulate the number of returned U.S. migrants living in different Mexican states and municipalities, we do not know where in the United States they went.

In this article, we employ a new source of data that overcomes these limitations. Specifically, we draw on data from Mexico's Matrícula Consular Program, which offers information on the place of origin of nearly one million undocumented migrants who came forward in 2006 to register at one of Mexico's fifty-three U.S. consulates. These data not only allow us to tabulate a large sample of undocumented migrants by state and region of origin in Mexico, but also to cross-reference this distribution by place of destination in the United States, thereby enabling us to identify specific flows of migrants between the two countries. 


\section{Mexico's Matricula Consular}

The Matrícula Consular, issued since 1871, is a registration document provided by Mexican consulates to nationals who reside abroad. The 1968 Vienna Convention on Consular Affairs, to which both Mexico and the United States are signatories, recognizes the legal right of foreign consulates to register their foreign-resident citizens and explicitly states that host countries cannot interfere with this right (see Elsea and Garcia 2005). The document was originally a paper certificate that recorded the foreign address of the bearer; but in the latter twentieth century, the ID card was laminated and reduced to wallet size, much like a U.S. driver's license.

The principal documents used by consular officials to verify the identity of the bearer are a Mexican birth certificate, a photo ID issued by the Mexican government, and proof of a local address in the United States, typically established by presentation of a utility bill. The cost of the card is about $\$ 27$ and must be renewed every five years (Instituto de los Mexicanos en el Exterior 2004; O'Neil 2003). According to a 2004 document published by the Instituto de los Mexicanos en el Exterior, an independent agency within the Mexican Foreign Ministry, some 304 financial institutions, 377 cities, 163 counties, 1,203 law enforcement agencies, and 7 U.S. states (mostly motor vehicle agencies) accept the Matrícula Consular for identity purposes, including Michigan, Nebraska, New Mexico, Texas, Utah, and Washington (Carter et al. 2005; National Immigration Law Center 2009).

Beginning in March 2002, the ID card underwent major changes and was replaced by a high security version (the Matrícula Consular de Alta Seguridad or High Security Consular Card) that incorporated thirteen state-of-the art security features such as a unique watermark, a hologram, and markers only visible using special equipment distributed to consulates and law enforcement authorities (Instituto de los Mexicanos en el Exterior 2004). Basically, the card uses the same security standards as the Mexican passport. According to a Los Angeles Times article, quoting figures from the Mexican government, roughly 4.7 million Mexican consular ID cards had been issued as of September 2005 (Dalton and Gordon 2005) and at least 5.7 million by the end of 2006 .

The Instituto de los Mexicanos en el Exterior has prepared a sample of nearly one million of these cards $(975,068)$ by geographic origins and destinations and published the data on the Internet at http://www ime.gob.mx/estados.htm. According to the website, the tally represents a complete count of all those who registered for the Matrícula between January 1 and October 31 of 2006. The information was compiled and 
processed by the Dirección General de Protección y Asuntos Consulares and the Dirección General de Telecomunicaciones e Informática of the Cancillería de la Secretaría de Relaciones Exteriores. We downloaded, cleaned, and arranged these data into two matrices, one cross-classifying registrants by state of origin and state of destination and another crossclassifying them by state of origin and city of destination in the United States. These two matrices provide the basic data for the analysis reported here.

Given that the program was launched to provide a secure form of identification for Mexicans living in the United States who otherwise would lack access to such documentation, we assume that all those registered are undocumented migrants, as persons legally in the United States would have no need for such documentation (they would carry passports with U.S. visas). Although we may safely assume Matrícula registrants are undocumented, they are probably not a representative crosssection of all undocumented migrants. Indeed, people who register are likely to be more established as U.S. residents-those people who have accumulated significant time in the United States and formed ties with American society and its institutions, thereby creating the need for an accepted form of identification to open bank accounts, get credit cards, obtain loans, open utility accounts, and so on. Recently arrived migrants and seasonal workers do not need such identification and are thus likely to be underrepresented in the consular data.

As of 2006, the Office of Immigration Statistics in the U.S. Department of Homeland Security estimated the number of Mexican undocumented migrants to be 6,570,000 (Hoefer, Rytina, and Campbell 2007), implying that the data we analyze constitute roughly a 15 percent sample of the population.. Unfortunately we know very little about how the sample was selected or how the selection process may have varied from place to place. The number of migrants registering at any given consulate no doubt depends partly on local stocks and flows, but registrations also likely reflect the proximity of consulates, the intensity of consular outreach efforts, the efforts of local immigrant organizations, as well as local policy decisions and law enforcement practices. Knowledge about the Matrícula probably also spreads differentially to migrants through social networks. Therefore, although the overall sampling rate may be 15 percent, the fraction possibly varies by city and region.

As noted previously, these people also cannot be assumed to be a random subset of all undocumented Mexican migrants, and probably represent the more well-established, firmly settled portion of the population. Indeed, according to a survey of 4,836 Mexican applicants for the Matrícula Consular in 2004 and 2005 conducted by the Pew Hispanic Center, only 17 percent had resided in the U.S. for two years or less (Suro 
2005). What the Matrícula Consular data do provide is good information on the geographic origins and destinations of a large sample of established undocumented Mexican migrants living in the United States who came forward to register during the first ten months of 2006.

\section{Origins of Undocumented Mexicans}

Several studies have examined trends in the geographic origins of Mexican migrants to the United States. Early in the twentieth century, U.S. labor recruiters targeted residents of Mexico's west-central region, which quickly came to comprise the heartland for migration to the United States. Labeled the "historical region" by Durand (1998), this area includes geographically large states such as Durango, Guanajuato, Jalisco, Michoacán, San Luís Potosí, and Zacatecas, as well as smaller states such as Aguascalientes, Colima, and Nayarit. According to information from a variety of sources examined by Durand and Massey (2003), from the 1920s onward, the share of migrants coming from the historical region was at least 50 percent and peaked peak at 60 to 70 percent in the late 1970s. Thereafter the regional origins of migrants began to shift and the share coming from the historical region began to fall. By the end of the twentieth century, the share of migrants from this region had dropped into the range of 40 to 50 percent (Durand, Massey, and Zenteno 2001; Massey, Durand, and Malone 2002; Durand and Massey 2003). By comparison, 23 percent of Mexico's population resided in the historical region as of the 2005 national census (INEGI 2006).

After 1980, new regions of out-migration arose in Mexico's central region (comprising the Distríto Federal, Guerrero, Hidalgo, México, Morelos, Oaxaca, Puebla, Querétaro, and Tlaxcala), along with the southeastern portion of the country (Campeche, Chiapas, Quintana Roo, Tabasco, Veracruz, and Yucatán) and the border region (Baja California, Chihuahua, Coahuila, Nuevo León, Sinaloa, Sonora, and Tamaulipas). The central region remained relatively unimportant as a sending area until 1980 , accounting for no more than 10 percent of U.S. migrants, but after that year, the percentage rose steadily to reach approximately 30 percent by the year 2000 (Durand and Massey 2003). The central region was home to 40 percent of Mexico's population in 2005 (INEGI 2006).

Mexico's southeastern region, for its part, remained insignificant as a migration source until the 1990s, when the transformation of the agrarian economy, the end of import substitution industrialization, and changes stemming from the implementation of the North American Free Trade Agreement triggered large-scale displacements from the countryside (Delgado Wise and Márquez Cuvarrubias 2007; Massey, Kalter, and Pren 2008). By the end of the century, migrants from this region com- 
Table 1. Regional and State Origins of Migrants Who Registered in Mexico's Matrícula Consular Program, 2006

\begin{tabular}{lrlr}
\hline Historical & $\mathbf{4 5 . 2}$ percent & Central & 37.4 \\
Aguascalientes & 0.9 & Distrito Federal & 6.6 \\
Colima & 0.7 & Guerrero & 7.6 \\
Durango & 2.9 & Hidalgo & 2.8 \\
Guanajuato & 8.8 & México & 5.1 \\
Jalisco & 10.8 & Morelos & 2.2 \\
Michoacán & 12.6 & Oaxaca & 5.5 \\
Nayarit & 1.8 & Puebla & 6.0 \\
San Luís Potosí & 2.9 & Queretaro & 1.2 \\
Zacatecas & 4.2 & Tlaxcala & 0.6 \\
Border & 10.7 & Southeast & 6.4 \\
Baja California & 1.1 & Campeche & 0.0 \\
Chihuahua & 2.3 & Chiapas & 1.2 \\
Coahuila & 1.1 & Quintana Roo & 0.2 \\
Nuevo León & 1.5 & Tabasco & 0.2 \\
Sinaloa & 2.0 & Veracruz & 4.3 \\
Sonora & 0.9 & Yucatán & 0.5 \\
Tamaulipas & 1.8 & & \\
\hline
\end{tabular}

prised 6 to 7 percent of the total (Durand and Massey 2003), compared with 17 percent of Mexico's total population (INEGI 2006).

Throughout history, Mexico's border region has never been a very large contributor of migrants to the United States. During the early years, this region was sparsely populated, and in more recent years, it has become the most rapidly growing portion of the Mexican economy with the highest wages. As a result, residents along the border have been much less likely to migrate to the United States than those of other regions (Fussell 2004a, 2004b). According to the Mexican Census of 2000, only 11 percent of all returned U.S. migrants lived in border states (Durand and Massey 2003), roughly half of the border region's share of the total Mexican population (21 percent) in 2005 (INEGI 2006).

In sum, as of the year 2000, around half of all U.S. migrants came from the historical region and around a third came from the central region, with 11 percent from the border region and 7 percent from the southeastern portion of the country (Durand and Massey 2003). These figures, of course, refer only to those migrants who went to the United States and returned during the five years prior to the census and they include persons with and without legal documents. The data summarized in Table 1, by contrast, includes only undocumented migrants who 
were living in the United States and came forward to register in 2006. Despite these differences, the regional distribution is quite similar, with 45 percent of all Matrícula registrants reporting origins in the historical region, 37 percent in the central region, 11 percent in the border region, and 6 percent in the southeastern region.

Consistent with earlier studies, the most important source states in the historical region are Michoacán (13 percent of all migrants), Jalisco (11 percent), Guanajuato (9 percent), Zacatecas ( 4 percent), San Luís Potosí ( 3 percent), and Durango ( 3 percent). Within the central zone, the largest sources are Guerrero ( 8 percent), the Federal District ( 7 percent), Puebla ( 6 percent), Oaxaca ( 5.5 percent), México ( 5 percent), Hidalgo ( 3 percent), and Morelos ( 2 percent). In the southeastern zone only two states appear to send significant numbers of migrants northward: Veracruz ( 4 percent) and Chiapas ( 1 percent). The leading source states in the border region are Chihuahua, Sinaloa, and Tamaulipas (each approximately 2 percent) followed by Baja California, Coahuila, and Nuevo León (each approximately 1 percent). These data confirm the shift away from the historical region and the significant participation of migrants from the central and southeastern regions, with the border region holding steady at around 10 percent of the total.

\section{Destinations of Undocumented Mexicans}

Just as the geographic origins of Mexicans have changed in recent years, so too have their destinations in the United States (Massey 2008). North as well as south of the border, the principal trend has been toward geographic diversification. Historically, the vast majority of Mexican immigrants went to just five states: the border states of California, Arizona, New Mexico, and Texas, and the industrial hub of Illinois. From 1910 to 1960, 90 percent of all Mexican immigrants lived in one of these states (Durand, Massey, and Charvet 2000). Early in the twentieth century Texas dominated, followed by California, Arizona, New Mexico, and Illinois. Over time, however, California came to dominate while Texas receded in importance. By 1960, California led with 42 percent of all Mexican immigrants, followed by Texas ( 36 percent), Arizona ( 6 percent), Illinois ( 5 percent), and New Mexico ( 2 percent). After 1960, the geography of Mexican migration grew even more concentrated, and by 1980, 57 percent of all Mexican immigrants lived in California alone, with 23 percent in Texas and 8 percent in Illinois, so that 88 percent of all Mexican immigrants lived in just three states (Durand, Massey, and Charvet 2000).

After 1986, however, the Immigration Reform and Control Act began to harden the busiest sectors of the Mexico-U.S. border selectively. In 1993, the U.S. Border Patrol launched an all-out militarization of the 
El Paso sector (Operation Blockade) followed by a parallel militarization in San Diego the following year (Operation Gatekeeper). In both sectors, this militarization was accompanied by the physical construction of walls. These actions diverted flows away from traditional destinations in California toward new locations elsewhere in the country (Massey, Durand, and Malone 2002). As late as 1990, 63 percent of recent Mexican immigrants (those arriving over the previous five years) still went to California, whereas 14 percent went to Texas, and 6 percent went to Illinois. By 2005, however, only 33 percent went to California, with 15 percent going to Texas and 5 percent to Illinois. After 1990, the share going to a state other than Illinois or one of the four border states climbed from approximately 13 percent to 40 percent in 2005 (Massey and Capoferro 2008).

Again, these figures refer to documented as well as undocumented Mexicans. Nonetheless, tabulations of those undocumented migrants who registered for the Matrícula Consular clearly confirm the shift away from California as a preferred destination. As Table 2 shows, only 40 percent of those who registered in 2006 did so in California, with 16 percent in Texas, 9 percent in Illinois, 4 percent in Arizona, and 1 percent in New Mexico, leaving 30 percent who registered outside of the border region or Illinois.

In Table 2, we organize the data using the regional classification developed by Durand and Massey (2003). In addition to the borderlands, other U.S. regions include the northwest (Idaho, Nevada, Oregon, Utah, and Washington), the Great Lakes (Illinois, Indiana, Michigan, Ohio, and Wisconsin), the northeast (Connecticut, Maine, Massachusetts, New Hampshire, New Jersey, New York, Pennsylvania, Rhode Island, and Vermont), the southeast (District of Columbia, Florida, Georgia, Maryland, North Carolina, South Carolina, Virginia, and West Virginia), the deep south (Alabama, Arkansas, Kentucky, Louisiana, Mississippi, and Tennessee), and the plains (Colorado, Iowa, Kansas, Minnesota, Missouri, Montana, Nebraska, North Dakota, Oklahoma, South Dakota, and Wyoming). According to this scheme, 61 percent of all undocumented Mexicans in 2006 lived in the borderlands, with 9 percent in the northwest, 12 percent in the Great Lakes, 3 percent in the northeast, 10 percent in the southeast, 2 percent in the deep south, and 5 percent in the plains.

The current geography of undocumented migration embraces not only new states of destination, but also new cities. Table 3 presents undocumented migrants tabulated by the consular city in which they registered, including all locations that comprised at least 1 percent of the total undocumented population and dividing them into "traditional" and "new" gateways. According to this division, 61 percent of all undocumented Mexicans lived in or around traditional gateway cities, whereas 
Table 2. State and Regional Location of Migrants Who Registered in Mexico’s Matrícula Consular Program, 2006

\begin{tabular}{|c|c|c|c|}
\hline Borderlands & 60.9 percent & Southeast & 9.6 \\
\hline Arizona & 4.1 & District of Columbia & 0.0 \\
\hline California & 39.9 & Florida & 2.7 \\
\hline New Mexico & 1.3 & Georgia & 2.9 \\
\hline Texas & 15.7 & Maryland & 0.5 \\
\hline Northwest & 8.5 & North Carolina & 2.3 \\
\hline Idaho & 0.2 & South Carolina & 0.6 \\
\hline Nevada & 3.0 & Virginia & 0.6 \\
\hline Oregon & 2.1 & West Virginia & 0.0 \\
\hline Utah & 1.3 & Deep South & 1.5 \\
\hline Washington & 1.8 & Alabama & 0.4 \\
\hline Great Lakes & 12.0 & Arkansas & 0.2 \\
\hline Illinois & 8.6 & Kentucky & 0.3 \\
\hline Indiana & 1.6 & Louisiana & 0.1 \\
\hline Michigan & 0.5 & Mississippi & 0.0 \\
\hline Ohio & 0.4 & Tennessee & 0.5 \\
\hline Wisconsin & 0.7 & Plains & 4.7 \\
\hline Northeast & 2.9 & Colorado & 2.1 \\
\hline Connecticut & 0.1 & Iowa & 0.4 \\
\hline Maine & 0.0 & Kansas & 0.3 \\
\hline Massachusetts & 0.1 & Minnesota & 0.8 \\
\hline New Hampshire & 0.0 & Missouri & 0.3 \\
\hline New Jersey & 0.9 & Montana & 0.0 \\
\hline New York & 1.4 & Nebraska & 0.5 \\
\hline Pennsylvania & 0.4 & North Dakota & 0.0 \\
\hline Rhode Island & 0.0 & Oklahoma & 0.2 \\
\hline \multirow[t]{2}{*}{ Vermont } & 0.0 & South Dakota & 0.0 \\
\hline & & Wyoming & 0.0 \\
\hline
\end{tabular}

31 percent lived in or near new gateways, together constituting 92 percent of all undocumented migrants who registered. The top five traditional gateways are Los Angeles (13 percent of all undocumented migrants), Chicago (10 percent), Dallas (6 percent), Santa Ana (5.5 percent), and Houston ( 5 percent). The top five new destination areas are Atlanta ( 4 percent), Phoenix ( 4 percent), Las Vegas ( 3 percent), Raleigh (3 percent), and Portland, Oregon ( 2 percent). Although Phoenix is in Arizona, a border state, prior to 1990 Mexican immigration to that state was small and historically went to the southern region around Tucson, with Phoenix being a magnet for Anglo-American migration from colder states in the north. 
Table 3. Distribution of Migrants Who Registered in Mexico's Matrícula Consular Program by Consulate of Registry, 2006

\begin{tabular}{lcll}
\hline Traditional Gateways & \multicolumn{3}{l}{ New Gateways } \\
\hline Los Angeles & 13.4 percent & Atlanta & 3.9 percent \\
Chicago & 9.8 & Phoenix & 3.6 \\
Dallas & 6.0 & Las Vegas & 3.1 \\
Santa Ana & 5.5 & Raleigh-Durham & 2.6 \\
Houston & 4.9 & Portland & 2.2 \\
San Francisco & 4.1 & Denver & 2.1 \\
San Diego & 3.5 & Indianapolis & 2.0 \\
San Jose & 2.9 & New York & 1.9 \\
Sacramento & 2.9 & Seattle & 1.7 \\
Oxnard & 2.8 & Salt Lake City & 1.7 \\
Fresno & 2.1 & Orlando & 1.6 \\
San Bernardino & 2.0 & Miami & 1.4 \\
Austin & 1.7 & Washington & 1.3 \\
San Antonio & 1.4 & Kansas City & 1.0 \\
Albuquerque & 1.0 & Minneapolis-St. Paul & 1.0 \\
Total & 61.0 & Total & 31.1 \\
\hline
\end{tabular}

\section{Region-to-Region Flows}

Table 4 begins the analysis of specific migratory flows by cross-tabulating Mexican region of origin with U.S. region of destination. Obviously the cross-tabulations do not represent flows in the strict sense, but refer instead to migrants in the sample from a particular source who registered at a particular destination. Nonetheless, for ease of expression we will specify origin-destination parings as flows and streams. As can be seen, migrants in the borderlands, the northwest, and the Great Lakes display very similar regional origins in Mexico, with just less than half coming from the historical region and most of the remaining migrants being divided evenly between the central and southeastern regions. What differs is the share of migrants emanating from Mexico's border region. Not surprisingly, at 14 percent, this percentage is highest among undocumented migrants living in the U.S. borderlands, whereas only 7 percent of migrants in the northwest come from a border state and just 4 percent of those in the Great Lakes region.

Mexicans living in the northeastern United States are distinct from those in other regions in that the overwhelming majority originate in one geographic area: Mexico's central region. Whereas only 9 percent 
Table 4. Mexican Region of Origin for Migrants Who Registered in Mexico's Matrícula Consular Program by U.S. Region of Destination

\begin{tabular}{lcccc}
\hline \multirow{2}{*}{ Origin in Mexico } & \multicolumn{4}{c}{ Destination in United States } \\
& Borderlands & Northwest & Great Lakes & Northeast \\
\cline { 2 - 5 } Historical & 49.1 percent & 48.4 percent & 48.7 percent & 8.9 percent \\
Border & 13.5 & 7.1 & 3.7 & 0.3 \\
Central & 32.7 & 38.1 & 40.3 & 84.9 \\
Southeast & 32.7 & 38.1 & 40.3 & 5.8 \\
Total & 100.0 & 100.0 & 100.0 & 100.0 \\
& Southeast & Deep South & Lower Plains & Upper Plains \\
& 29.9 & 37.4 & 46.4 & 27.4 \\
Historical & 5.1 & 6.1 & 19.2 & 7.1 \\
Border & 50.3 & 40.9 & 28.4 & 57.5 \\
Central & 14.7 & 15.6 & 6.1 & 8.0 \\
Southeast & 100.0 & 100.0 & 100.0 & 100.0 \\
Total & & & &
\end{tabular}

of migrants in the northeast came from the historical region and just 6 percent from the southeastern region, fully 85 percent came from the central region, most prominently from the state of Puebla (more on this later). Two other U.S. regions show a disproportionate concentration of Mexicans from the central region. In the upper plains of the United States (Minnesota, Montana, North Dakota, and South Dakota), 58 percent of all undocumented Mexicans were from this region, followed by 27 percent from the historical region, 8 percent from the southeastern region, and 7 percent from the border region. Likewise, in the southeastern United States, 50 percent of migrants came from the central region, compared with 30 percent from the historical region, 15 percent from the southeastern region, and 5 percent from the border region.

Migrants living in the deep south were relatively balanced between origins in the historical (37 percent) and central regions ( 41 percent), with 16 percent coming from the southeast and 6 percent from the border area. Undocumented migrants living in the lower plains region (Colorado, Iowa, Kansas, Missouri, Nebraska, Oklahoma, and Wyoming) were dominated by those with origins in the historical region ( 46 percent) but also showed an unusually high representation of migrants from the border states (19 percent), with 28 percent coming from the central region and 6 percent from the southeast.

In Table 5 we switch viewpoints to consider where in the United States Mexican migrants went. The first column shows U.S. region of des- 
Table 5. U.S. Region of Destination for Migrants Who Registered in Mexico's Matrícula Consular by Region of Origin in Mexico

\begin{tabular}{lcccc}
\hline \multirow{2}{*}{ Destination in U.S. } & \multicolumn{4}{c}{ Mexican Region of Origin } \\
& Historical & Border & Central & Southeast \\
\hline Borderland & 77.1 percent & 53.2 percent & 65.6 percent & 44.8 percent \\
Northwest & 5.6 & 8.6 & 9.0 & 8.5 \\
Great Lakes & 4.2 & 12.9 & 12.8 & 13.6 \\
Northeast & 0.1 & 6.5 & 0.6 & 2.6 \\
Southeast & 4.5 & 12.9 & 6.3 & 22.0 \\
Deep South & 0.8 & 1.6 & 1.2 & 3.6 \\
Lower Plains & 7.1 & 3.0 & 4.0 & 3.7 \\
Upper Plains & 0.6 & 1.3 & 0.5 & 1.0 \\
Total & 100.0 & 100.0 & 100.0 & 100.0 \\
\hline
\end{tabular}

tination for migrants from the historical region. Overwhelmingly people from the traditional heartland of migration have gone to the U.S. borderlands, with 77 percent of all undocumented migrants from this region registering at a consulate in Texas, New Mexico, Arizona, or California, with by far the largest share in California. After the borderlands, migrants from the historical region were most likely to go to the lower plains ( 7 percent), the northeast ( 6 percent), the southeast ( 4.5 percent), and the Great Lakes ( 4 percent).

Although migrants from the historical region were most concentrated in their destination choices, not far behind were undocumented migrants from the central region, 66 percent of whom could be found in the borderlands (again predominantly California), followed by the Great Lakes (13 percent), the northwest (9 percent), the southeast (6 percent), and the lower plains ( 4 percent). Less concentrated still were migrants from Mexico's border states, only 53 percent of whom reside in the U.S. borderlands, with 13 percent each in the Great Lakes and the southeast, and 9 percent in the northwest, 7 percent in the northeast, and 3 percent in the lower plains. By far the most diverse in terms of destination were migrants from Mexico's southeast, 45 percent of whom went to the borderlands, 22 percent to the southeast, 14 percent to the Great Lakes, 9 percent to the northwest, and 4 percent each to the deep south and lower plains.

Table 6 compares the regional origins of undocumented migrants who went to traditional and new gateway cities. Whereas 51 percent of migrants who went to the former originated in Mexico's historical region, only 35 percent of those who went to the latter did so. Among 
Table 6. Region of Origin of Migrants Who Registered in Mexico's Matrícula Consular in Traditional and New Gateway Cities

Mexican Region of Origin Consulate of Registry in United States

\begin{tabular}{lcc} 
& Traditional Gateways & New Gateways \\
\hline Historical & 50.7 percent & 35.3 percent \\
Border & 7.9 & 10.2 \\
Central & 36.6 & 45.8 \\
Southeast & 4.7 & 8.6 \\
Total & 100.0 & 100.0 \\
\hline
\end{tabular}

migrants in new gateways, the central region predominated, accounting for 46 percent of the total, compared with just 37 percent in traditional gateways. New gateway cities also displayed a greater representation of border states ( 10 percent compared with 8 percent in traditional gateways) and southeastern states (9 percent compared with 5 percent in traditional gateways). In sum, migrants in traditional gateway cities were more likely to come from the historical heartland whereas migrants in new gateway cities originated from more diverse regions in Mexico.

\section{Specific State-to-State Flows}

In addition to the summary descriptions presented so far, the Matrícula Consular data enable a more detailed analysis of specific state-to-state flows. The 32-51 state-by-state data matrix yields 1,632 cells corresponding to specific pairings of Mexican and U.S. states (including the Mexico's D.F. and the United States' District of Columbia). These cells range in size from 0 to around 64,000 persons, each corresponding to a particular state-to-state exchange of migrants. Figure 1 presents data on the largest flows in the Mexico-U.S. migration system by showing the relative size of cells containing more than 10,000 persons.

The most obvious fact about these large state-to-state flows is the overwhelming dominance of California as a destination and the complete monopoly of traditional states as destinations. Of seventeen flows in excess of 10,000 persons, twelve involve destinations in California, with three in Texas and one each in Illinois and Arizona. All of the top seven flows in terms of size involve pathways to California, led by streams between Jalisco and California and Michoacán and California, each comprising around 64,000 persons. These flows are followed by a Guerrero-toCalifornia stream of 30,000 persons, and three streams containing around 26,000 persons: Distrito Federal-to-California, Guanajuato-to-California, 
Figure 1. State-to-state flows in excess of 10,000 persons.

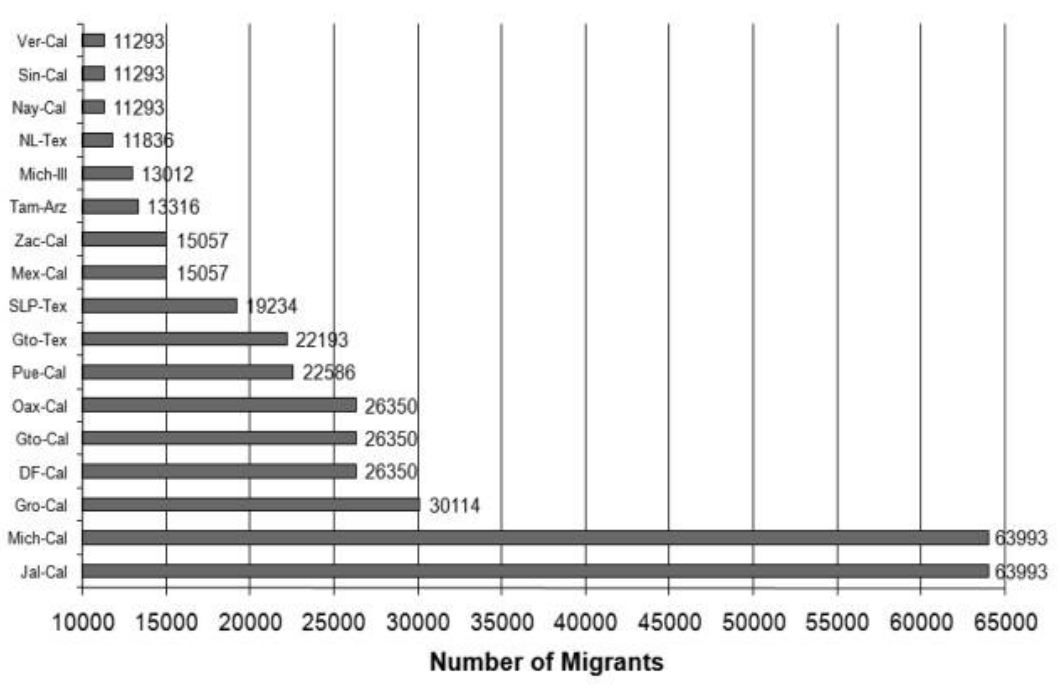

and Oaxaca-to-California. Puebla-to-California comes in at seventh place with around 23,000 migrants.

Rounding out the top ten flows are two Texas-oriented flows and one additional stream into California. The number of migrants who went from Guanajuato to Texas stood at around 22,000, followed by 19,000 between San Luís Potosí and Texas and a tie for the tenth spot with 15,000 migrants between México and California and Zacatecas and California. The remaining migration streams above 10,000 include Tamaulipas-toArizona (approximately 13,000), Michoacán-to-Illinois $(13,000)$, Nuevo León-to-Texas $(12,000)$, plus three more into California: Nayarit-toCalifornia, Sinaloa-to-California, and Veracruz-to-California, each weighing in at around 11,000 migrants.

In Figure 2, we show the next tier of state-level flows by depicting those ranging in size from 6,000 to 10,000 persons, and here California cedes its dominance to a greater representation by Texas and Illinois as well as one new state of destination. Of the fifteen migrant streams shown in the figure, six involve Texas, four involve Illinois, and one involves New York, leaving just four focused on California. The largest streams in the second tier of state-to-state flows are the Guanajuato-to-Illinois and Guerrero-to-Illinois streams at just less than 10,000 persons, followed by Michoacán-to-Texas and Zacatecas-to-Texas at just less than 9,000, and Jalisco-to-Illinois at just greater than 8,000 migrants.

The next four streams, which come in at approximately 7,500 persons each, flow into California, and include Baja-California-to-California, 


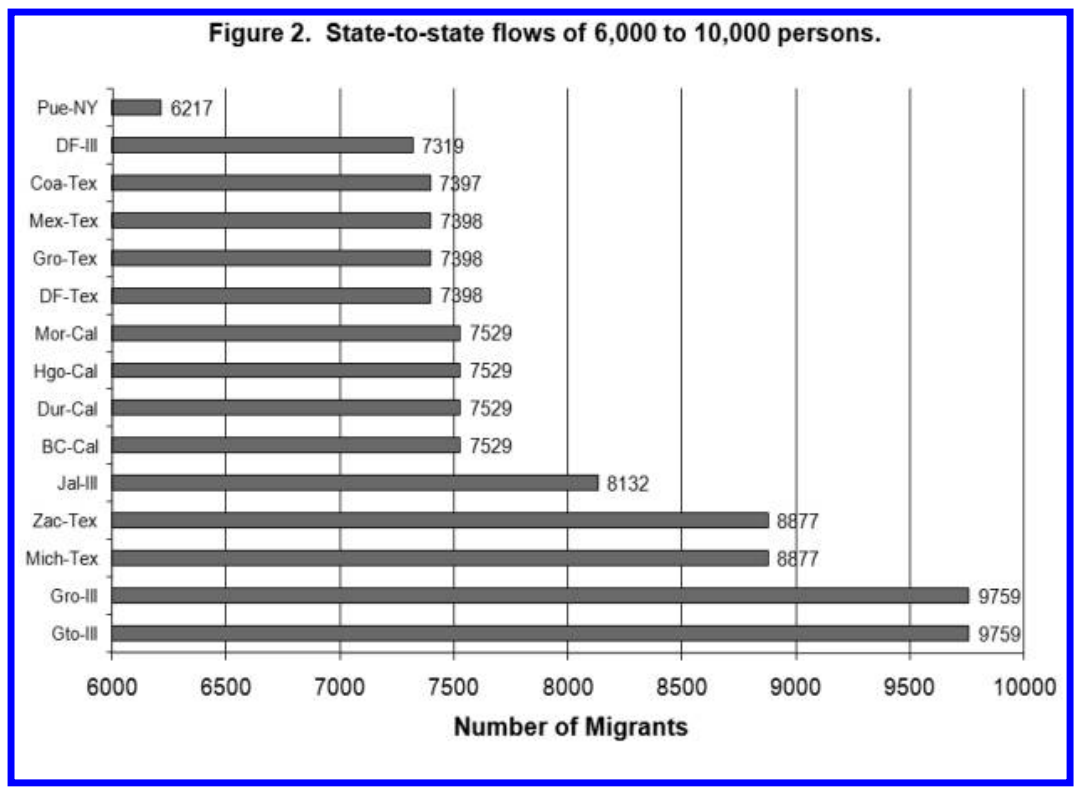

Durango-to-California, Hidalgo-to-California, and Morelos-to-California. These four largest streams are focused on Texas with around 7,400 persons each: Distrito Federal-to-Texas, Guerrero-to-Texas, México-to-Texas, and Coahuila-to-Texas. The final two streams shown in Figure 2 are those between the Distrito Federal and Illinois $(7,300)$ and Puebla and Illinois $(6,200)$.

Finally, Figure 3 shows the third tier of migration streams by focusing on state-to-state pairings involving 4,000 to 6,000 persons. In this figure, the dominance of Texas and Illinois over California continues. Of the thirteen flows depicted, four go into Texas and four into Illinois compared with just one each into California, Arizona, New Mexico, Nevada, and Oregon. The four largest are Durango-to-Texas, Jalisco-toTexas, Veracruz-to-Texas, and Chihuahua-to-New Mexico at around 5,900 each, followed by México-to-Illinois at 5,700, Sonora-to-Arizona at 5,000, Durango-to-Illinois at 4,900, and Michoacán-to-Oregon at 4,600. The last five in this set of migrant streams range in size from 4,000 to approximately 4,400 persons and include the state pairings of ChihuahuaTexas, Jalisco-Nevada, Sinaloa-California, Veracruz-Illinois, and ZacatecasIllinois.

The forty-five flows depicted in Figures 1-3 account for approximately 60 percent of all undocumented migrants, thus highlighting the dominance of traditional regions of origin and destination within the Mexico-U.S. migration system. Seventeen of all streams flowed into California, thirteen into Texas, nine into Illinois, two into Arizona, and one 


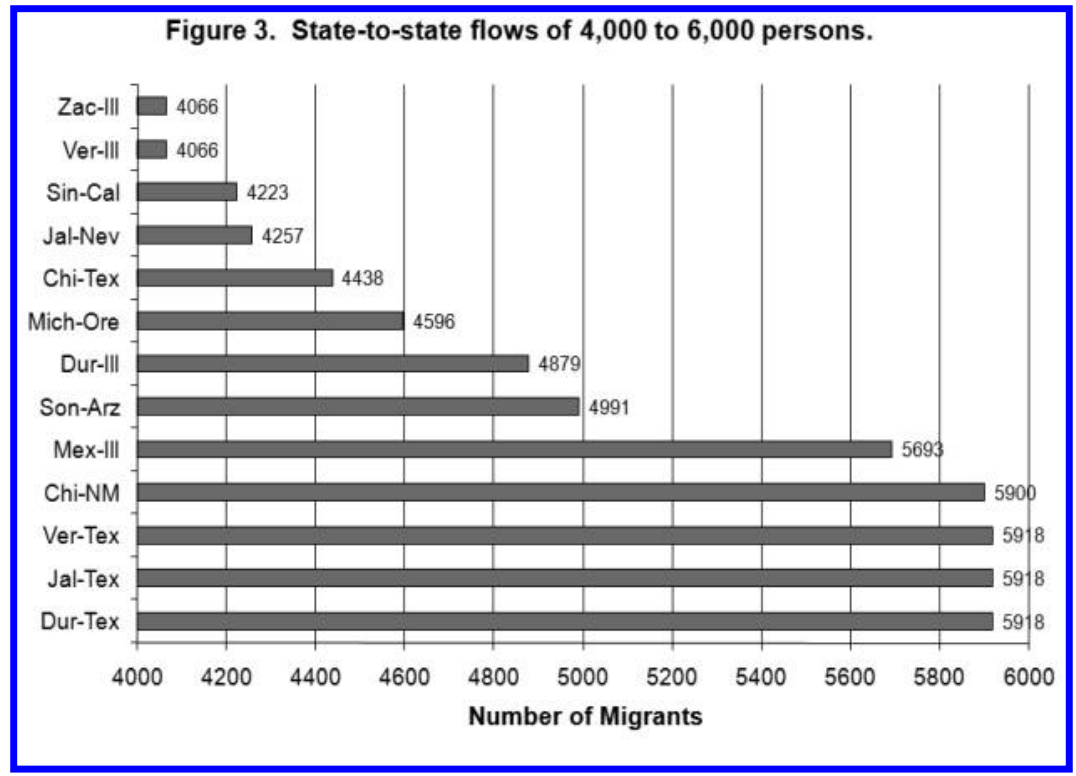

into New Mexico. Flows into other states involved only single instances, as with New York, Oregon, and Nevada. Likewise, of the forty-five flows considered, nineteen originated in the historical region, fourteen in the central region, nine in the border region, and just three in the southeast. The Mexico-U.S. migration system, in other words, continues to be dominated by flows from Mexico's historical region into traditional U.S. states of destination.

\section{Specific State-to-City Flows}

The state-to-city matrix we derived from the Matrícula data can be used to study flows into particular urban areas of the United States. The first fifteen of these flows are depicted in Figure 4, which shows state-to-city streams in excess of 8,000 persons. Once again we observe the dominance of traditional destinations. Of the fifteen city-oriented migration streams, thirteen involve traditional gateways, with five going to Los Angeles, five to Chicago, two to San Francisco, and one to Dallas. The streams going into Los Angeles are quite large, led by the Jalisco-to-Los Angeles stream of 24,600 persons, and including as well large flows from Michoacán (16,400), Puebla (11,100), the Distrito Federal $(10,500)$, and México (8,500). Likewise, flows into Chicago are all in excess of 9,000 persons, including large streams from Michoacán $(14,100)$, México $(10,800)$, Guerrero $(10,700)$, Guanajuato $(10,650)$, and Jalisco $(9,200)$. The Michoacán-to-San Francisco stream stands at 9,400 persons, whereas 
Figure 4. State-to-city flows in excess of 8,000 persons.

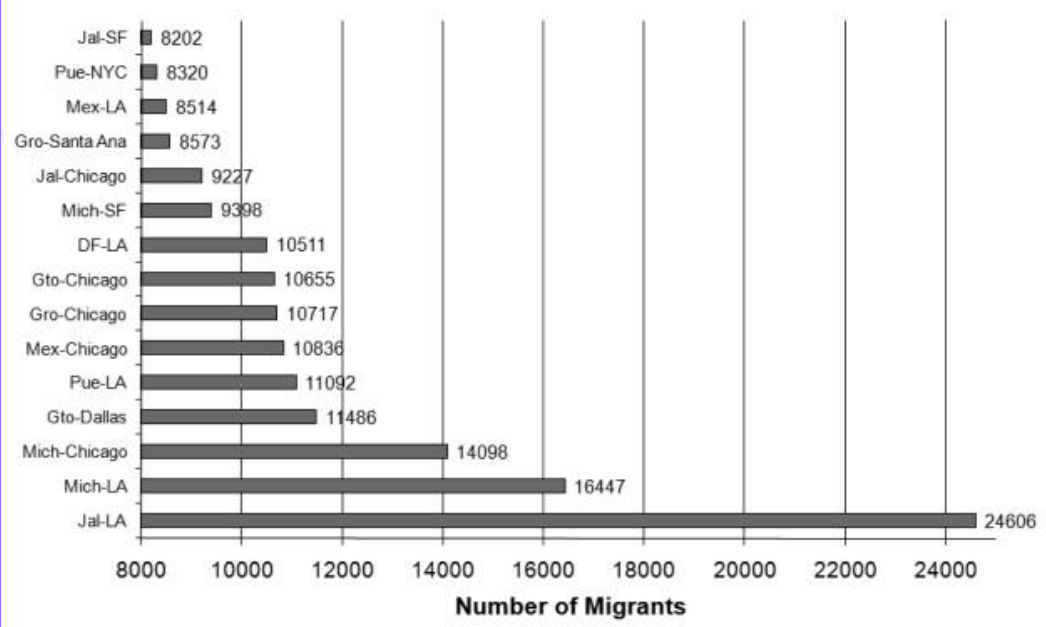

the Jalisco-to-San Francisco stream comprise 8,200 persons and the one flow into Dallas (from Guanajuato) stands at 11,500 persons.

The only flow involving a new gateway among the top fifteen migration stream is that between Puebla and New York City. The strong connection between Puebla and destinations in the northeast has already been noted, and the Puebla-New York circuit has been the subject of a major ongoing study by Smith (2006). What the results of Figure 4 indicate is that whereas most Mexicans in New York might be from Puebla, most migrants from Puebla did not go to New York. As seen in Figure 4, more Poblanos lived in Los Angeles $(11,500)$ than in New York $(8,300)$. Although 45 percent of all Mexicans in New York were from Puebla and Oaxaca was next at just 11 percent, among migrants from Puebla, only 15 percent went to New York compared with 20 percent to Los Angeles, 8 percent to Chicago, 7 percent to Santa Ana, 5 percent to Las Vegas, 4 percent to Philadelphia, and 3 percent each to Houston, Indianapolis, Raleigh, and Washington, and 29 percent scattered among 20 other cities. Although not fully appreciated heretofore, migration from Puebla to the United States is far more diverse than just migration into the New York metropolitan area.

Figure 5 shows second-tier state-to-city flows by depicting streams comprised of 5,000 to 8,000 persons. Again traditional gateway cities dominate. Of the sixteen state-to-city flows shown, only one involves a new gateway, and that one-between Jalisco and Las Vegas-is smallest at just 5,100 persons. In contrast, four streams flow into Los Angeles, including 7,900 persons from Guerrero, 7,700 from Oaxaca, 6,800 from Zacatecas, 


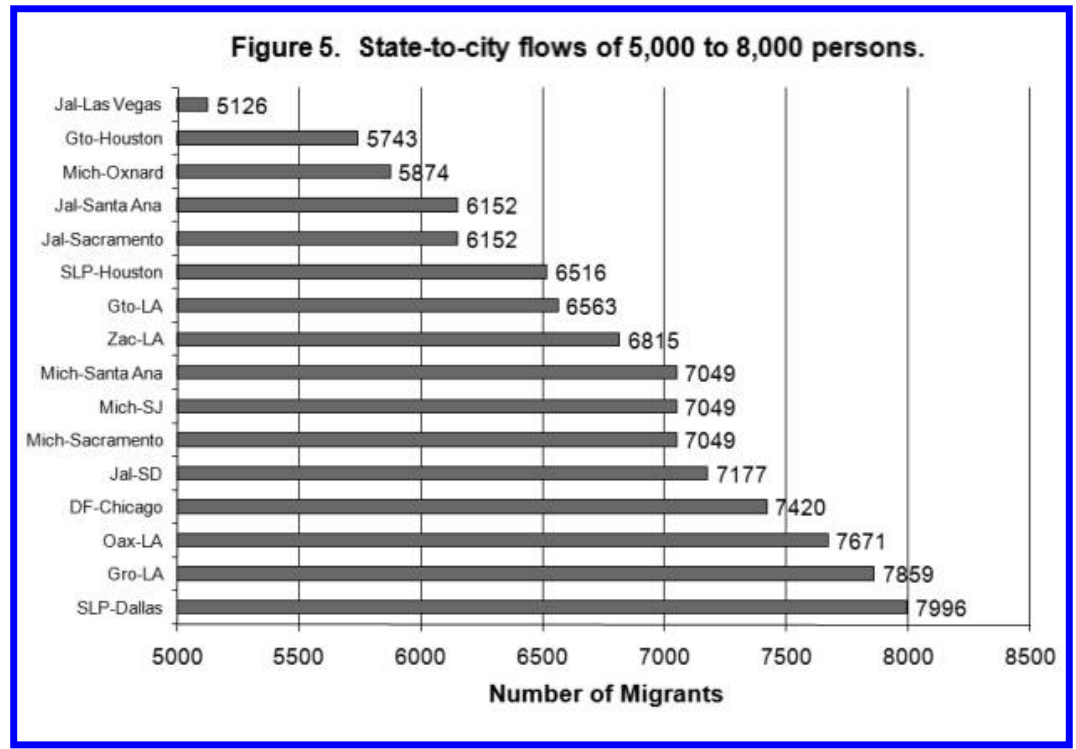

and 6,600 from Guanajuato. Likewise, three streams flow into traditional Texan gateways, with 8,000 proceeding from San Luís Potosí to Dallas, 6,500 from San Luís Potosí to Houston, and 5,700 from Guanajuato to Houston. The remaining flows in Figure 5 all involve cities in California, including Jalisco-to-San Diego (7,200), Michoacán-to-Sacramento (7,000), Michoacán-to-Santa Ana (7,000), Jalisco-to-Sacramento $(6,200)$, Jaliscoto-Santa Ana (6,200), and Michoacán-to-Oxnard (5,900).

The final tier of state-to-city flows we consider involves nineteen streams of 4,000 to 5,000 persons, which are graphed in Figure 6. Although flows to traditional gateway cities continue to dominate, new gateways begin to appear as we move down the size hierarchy. In this list, the new gateway city of Atlanta makes its first appearance with two discernable streams, along with one stream going to Portland, Oregon. Nonetheless, most of the flows shown in the diagram pertain to traditional gateways, with four going to Chicago, two to Houston, two to Dallas, two to Los Angeles, two to Santa Ana, and one each to Fresno and San Jose.

The four flows into Chicago include significant migrant streams emanating in Durango $(4,800)$, Veracruz $(4,700)$, Zacatecas $(4,600)$, and Puebla $(4,400)$. The four streams into Texas gateways include two into Dallas (Zacatecas-to-Dallas at 4,900 and México-to-Dallas at 4,600) and two into Houston (Tamaulipas-to-Houston at 4,100 and Nuevo León-toHouston at 4,000). In California, we observe two flows into Los Angeles (4,500 from Sinaloa and 4,200 from Nayarit), two into Santa Ana (4,600 
Figure 6. State-to-city flows of 4,000 to 5,000 persons.

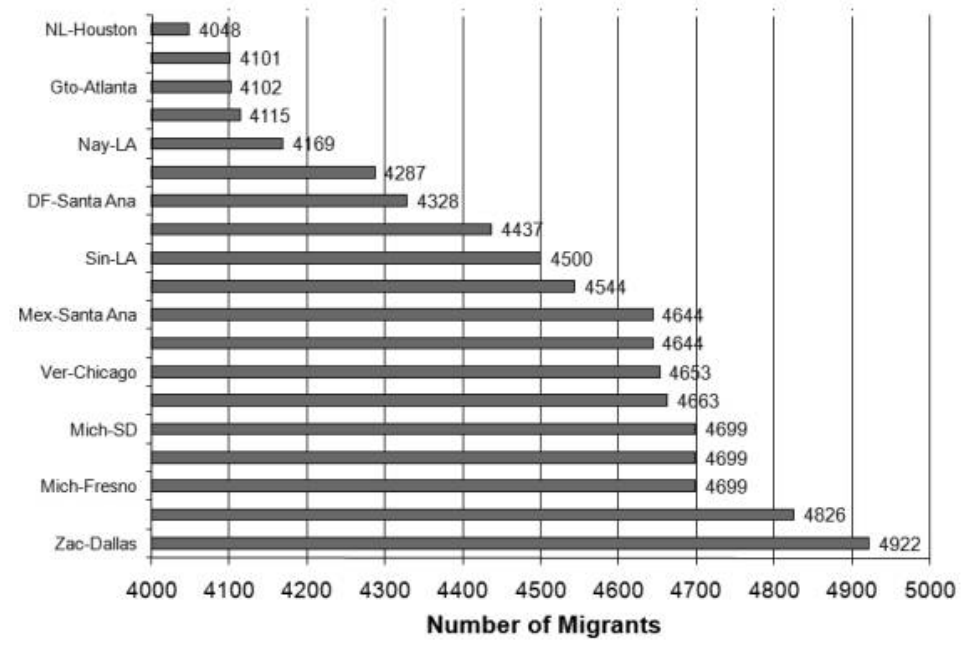

from México and 4,300 from the Distrito Federal), and one each into San Diego (4,700 from Michoacán), Fresno (4,700 from Michoacán), and San Jose (4,100 from Jalisco).

As already noted, in addition to these well-established flows into gateway cities, streams into three new gateways make their appearance in this figure, including two into Atlanta (4,300 from Guerrero and 4,100 from Guanajuato) and one into Portland, Oregon (4,700 from Michoacán). The final flow shown in Figure 6, from Chihuahua to Albuquerque, though not a major flow historically is more traditional as it involves a stream going into New Mexico's largest city from a neighboring Mexican state.

The fifty state-to-city pathways shown in the preceding three figures account for around 40 percent of all migrants covered by the Matrícula Consular program; and again these data illustrate the centrality of well-established migratory pathways in the Mexico-U.S. system, with eleven streams focused on Los Angeles, ten on Chicago, and eight on Dallas or Houston, compared with just two into Atlanta, one into New York, one into Las Vegas, and one into Portland. If we consider smaller flows between 2,000 and 4,000 persons (not shown here), much the same pattern prevails. Most of the streams involve movements into traditional gateway cities in historical states of destination, interspersed here and there with new gateways in new states. 


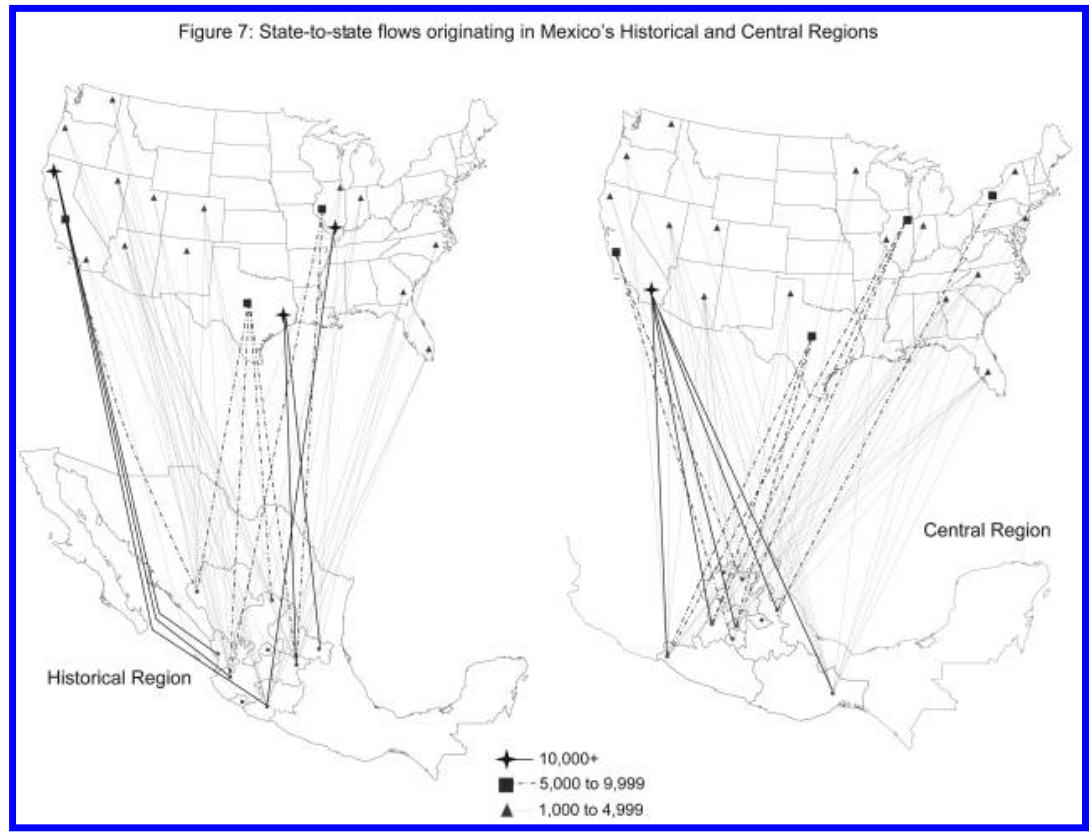

\section{The Geographic Structure of Mexico-U.S. Migration}

For reasons of economy, our analyses to this point have focused only on those flows that exceeded 4,000 persons in the Matrícula data. The full geographic structure of undocumented migration, of course, encompasses many smaller flows, and in order to visualize the full scope of the system's spatial structure, we prepared figures that drew lines connecting specific Mexican and U.S. states, with a solid line going into a star in a U.S. state to indicate a large flow in excess of 10,000 persons, a dashed line going into a square to indicate a medium flow of 5,000 to 9,999 persons, and a solid line going into a triangle to indicate a small flow of 1,000 to 4,999 persons. Flows in excess of 1,000 persons make up 81 percent of the sample and thus offer a comprehensive view of the system's geographic structure.

Figure 7 shows specific state-to-state flows originating in Mexico's historical and central regions. The spatial organization of migration from the historical region is characterized by very large flows into the three principal migrant-receiving states, with three going into California, two into Texas, and one into Illinois. California also receives one medium and two small-sized flows, whereas Illinois receives two medium and three small flows, with three more small flows going into neighboring Indiana. Texas, however, has four medium-sized flows and no small flows in addition to its two large flows. All the rest of the flows out of the his- 


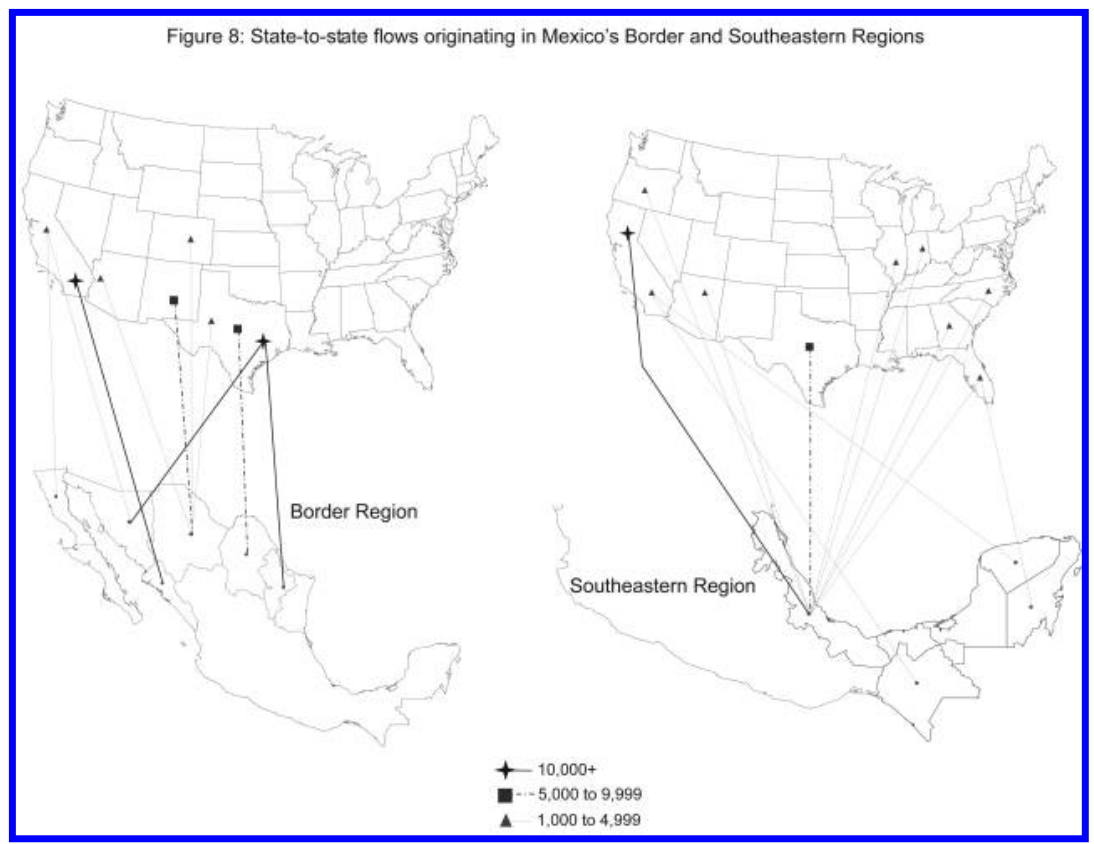

torical area are small, in the 1,000 to 4,999 range, and the large majority go into the western states such as Washington, Oregon, Nevada, Utah, Colorado, and Arizona, with one additional small flow into New Mexico. The only flows into the eastern United States are two into Florida and North Carolina and three into Georgia. In all, migration streams flow out of the historical region and into fourteen U.S. states.

In contrast, the streams flowing out of the central region are at once more numerous and more diverse, going into fifteen states with more in the Midwest and Northeast and fewer in the West. The system is dominated by five large flows into California, with only medium and small flows into other states. California also receives two medium flows, with other medium-sized flows going into Texas (three streams), Illinois (two), and New York (one). All other streams in the system are small, less than 5,000 . As with the historical migration system, the central migratory system has multiple small flows into western states such as Washington, Oregon, Nevada, Utah, and Arizona, but none into New Mexico or Colorado. In the Midwest, we observe flows into Minnesota and Indiana as well as Illinois, and in the East, we encounter streams into New York and New Jersey as well as into North Carolina, Georgia, and Florida.

Figure 8 summarizes the geographic structure of migration from the border and southeastern regions. Obviously, these systems are less com- 
plex, with fewer streams going into a smaller number of states. Not surprisingly, streams out of Mexico's border region focus overwhelmingly on states in the U.S. borderlands, with two large flows into Texas and one into California, with medium flows into Texas and New Mexico and small flows into California, Texas, Arizona, and Colorado. Thus, the border migration systems only involve U.S. states that were part of Mexico before 1848 . The southeastern system, in contrast, is more diverse in terms of destination. Although there is only one large flow into California, we observe a medium flow into Texas and small flows into Oregon and Arizona as well as Illinois and Indiana in the Midwest and Florida, Georgia, and North Carolina in the Southeast.

\section{Conclusion}

Over a century of growth and evolution, the Mexico-U.S. migration system has developed a stable, slowly changing geographic structure dominated at its core by flows out of the historical heartland for migration to the United States into traditional gateway cities in key migrant-receiving states. The dominance of heartland-to-gateway flows in the system probably peaked in the 1980 s, however, and since then the system has slowly but steadily evolved to incorporate new geographic origins and destinations. During the 1990s Mexico's central region rose in prominence as a source for U.S. migrants and by 2006 accounted for roughly a third of all undocumented migrants. Although the majority of migrants from the central region went to traditional destinations in California, Texas, Illinois, and the Southwest, the flows also diversified to incorporate new destinations in the Midwest, Northeast, and Southeast, with significant streams into New York-New Jersey, North Carolina, Georgia, and Florida. During the 1990s, Mexico's southeastern states emerged as a significant sending region, with significant streams into Florida, Georgia, and North Carolina as well as to the Chicago region and the border states. Mexico's border region has been a consistent but relatively minor participant in the migratory system, with its outflows constituting approximately 10 percent of the migratory system, all focused on border states in the southwestern United States.

The incorporation of so many new destination areas into the Mexico-U.S. migration system perhaps helps to explain why undocumented migration has risen to become such a prominent and divisive national issue. Unlike the era before 1990, when Mexican immigration was a regional phenomenon affecting just three states, it has now become a national phenomenon affecting all fifty states. Moreover, whereas before 1990 Mexicans went to states with long histories of immigration, after 1990 , they increasingly migrated to states that not only had not seen Mex- 
ican immigrants before, but also had not seen any immigrants in existing memory and had thought of themselves as ethnically and culturally homogenous, or at least characterized by a stable black-white color line.

The new geography of Mexican immigration also suggests the need to expand studies of immigrant adaptation and assimilation away from traditional places of destination, such as Chicago and Los Angeles, to incorporate places such as Atlanta, Charlotte, Las Vegas, and Minneapolis that have come to house large and growing, but recently formed, populations of Mexican immigrants. These are the locations in which Mexican nationals will increasingly be absorbed into American culture and society and in which the next generation of Mexican Americans will be born and raised.

\section{References:}

Carter, Adrienne, Roger O. Crockett, Brian Grow, and Geri Smith. 2005.

"Embracing Illegals." Business Week, July 18, 2005. http://www.business week.com/magazine/content/05_29/b3943001_mz001.htm.

Delson, Jennifer, and Anna Gorman. 2005. "Mexico's ID Makes Major Gains in U.S.” Los Angeles Times, September 27, 2005, B2.

Durand, Jorge. 1998. "Nuevas Regiones Migratorias." In René M. Zenteno, ed., Población, Desarrollo y Globalización: V Reunión de Investigación Socio-Demográfica en México. Vol.2., pp. 101-115 (México: Sociedad Mexicana de Demografía-El Colegio de la Frontera Norte).

Durand, Jorge, and Douglas S. Massey. 2003. Clandestinos: Migración MéxicoEstados Unidos en los Albores del Siglo XXI (México: Universidad Autónoma de Zacatecas-Miguel Angel Porrúa).

Durand, Jorge, Douglas S. Massey, and Fernando Charvet. 2000. "The Changing Geography of Mexican Immigration to the United States: 1910-1996." Social Science Quarterly 81: 1-15.

Durand, Jorge, Douglas S. Massey, and René M. Zenteno. 2001. "Mexican Immigration to the United States: Continuities and Changes." Latin American Research Review 36: 107-127.

Elsea, Jennifer K., and Michael John García. 2005. "Implications of the Vienna Convention on Consular Relations upon the Regulation of Consular Identification Cards." Congressional Research Service Report RS21627, May 23.

Fussell, Elizabeth. 2004a. "Sources of Mexico's Migration Stream: Rural, Urban, and Border Migrants to the United States." Social Forces 82: 937-967.

_ 2004b. "Tijuana's Place in the Mexican Migration Stream: Destination for Internal Migrants or Stepping Stone to the United States?” In Jorge Durand and Douglas S. Massey, eds., Crossing the Border: Research from the Mexican Migration Project (New York: Russell Sage Foundation).

Gamio, Manuel. 1930. Mexican Immigration to the United States (Chicago: University of Chicago Press). 
INEGI (Instituto Nacional de Estadística, Geografía e Informática). 2006. "Población Total, Edad Mediana y Relación Hombres-Mujeres por Entidad Federativa Según Sexo." Conteo de Población y Vivienda 2005 (accessed online at http://www.inegi.org.mx/est/contenidos/espanol/sistemas/ conteo2005/datos/00/pdf/cpv00_pob_4.pdf).

Hoefer, Michael, Nancy Rytina, and Christopher Campbell. 2007. "Estimates of the Unauthorized Immigrant Population Residing in the United States: January 2006." Population Estimates, August 2007, Office of Immigration Statistics, U.S. Department of Homeland Security. http://www.dhs.gov/ files/statistics/publications/\#2.

Instituto de los Mexicanos en el Exterior. 2004. "Most Frequently Asked Questions Regarding the Matrícula Consular (MCAS).” Mexican Foreign Ministry, 20 July 2004. http://portal.sre.gob.mx/ime/pdf/mcas.pdf.

Massey, Douglas S. 2008. New Face in New Places: The Changing Geography of American Immigration (New York: Russell Sage Foundation).

Massey, Douglas S., and Chiarra Capoferro. 2008. "The Geographic Diversification of U.S. Immigration." In Douglas S. Massey, ed., New Faces in New Places: The Changing Geography of American Immigration, pp. 25-50 (New York: Russell Sage).

Massey, Douglas S., Jorge Durand, and Nolan J. Malone. 2002. Beyond Smoke and Mirrors: Mexican Immigration in an Age of Economic Integration (New York: Russell Sage Foundation).

$\rightarrow$ Massey, Douglas S., and René M. Zenteno. 2000. "A Validation of the Ethnosurvey: The Case of Mexico-U.S. Migration." International Migration Review 34: 765-792.

National Immigration Law Center. 2009. http://www.nilc.org/immspbs/DLs/ state_dl_rqrmts_ovrvw_200904-27.pdf (accessed May 18, 2009).

O'Neil, Kevin. 2003. "Consular ID Cards: Mexico and Beyond" Migration Policy Institute, April 2003. http://www.migrationinformation.org/USfocus/ display.cfm? $\mathrm{ID}=115$.

Suro, Roberto. 2005. "Survey of Mexican Migrants: Part One." Pew Hispanic Center, March 2. http://pewhispanic.org/files/reports/41.pdf.

Taylor, Paul S. 1934. Mexican Migration Statistics: University of California Publications in Economics, vol. 12, no. 3 (Berkeley: University of California Press). 